\title{
Effect of GRM7 polymorphisms on the development of noise-induced hearing loss in Chinese Han workers: a nested case-control study
}

Peipei $Y u^{1,2}$, Jie Jiao ${ }^{2}$, Guoshun Chen ${ }^{3}$, Wenhui Zhou ${ }^{2}$, Huanling Zhang ${ }^{3}$, Hui Wu ${ }^{2}$, Yanhong Li ${ }^{2}$, Guizhen Gu ${ }^{2}$, Yuxin Zheng ${ }^{4}$, Yue $\mathrm{Yu}^{5}$ and Shanfa $\mathrm{Yu}^{2^{*}}$ (i)

\begin{abstract}
Background: Noise-induced hearing loss (NIHL) is a complex, irreversible disease caused by the interaction of genetic and environmental factors. In recent years, a great many studies have been done to explore the $\mathrm{NIHL}$ susceptibility genes among humans. So far, high powerful detections have been founded that genes of potassium ion channel genes (KCNQ4 and KCNE1), catalase (CAT), protocadherin 15 (PCDH15), myosin 14 (MYH14) and heart shock protein (HSP70) which have been identified in more than one population may be associated with the susceptibility to NIHL. As for metabolic glutamate receptor7 gene (GRM7), a lot of researches mainly focus on age-related hearing loss (ARHL) and the results have shown that the polymorphisms of GRM7 are linked to the development of ARHL. However, little is known about the association of GRM7 and the susceptibility to NIHL. Therefore, the aim of this study was to explore the effect of GRM7 polymorphisms on the susceptibility to NIHL.

Methods: A nested case-control study based on the cohort in a Chinese steel factory was implemented in 292 cases and 584 controls matched with the same sex, the age difference $\leq 5$ years old, the same type of work, duration of occupational noise exposure $\leq 2$ years. Five single nucleotide polymorphisms (SNPs) of GRM7 were gained through selecting and genotyping SNPs. Conditional logistic regression analysis was used to assess the main effect of GRM7 polymorphisms on the susceptibility to NIHL and the gene-by-environment interaction. Furthermore, the gene-bygene interactions were analyzed by generalized multiple dimensionality reduction (GMDR).

Results: This research discovered for the first time that the mutant allele C in rs1485175 of the GMR7 may decrease individuals' susceptibility to NIHL. The interaction between rs 1485175 and cumulative noise exposure (CNE) at high level was found after the stratification according to CNE $\left(p / p_{\text {bon }}=0.014 / 0.007, \mathrm{OR}=0.550,95 \%\right.$ Cl: 0.340-0.891). Permutation test of GMDR suggested that rs1920109, rs1485175 and rs9826579 in GRM7 might interact with each other in the process of developing $\mathrm{NIHL}(p=0.037)$.
\end{abstract}

Conclusions: The results suggest that the mutant allele C of rs1485175 in GRM7 may reduce the susceptibility to $\mathrm{NIHL}$ in Chinese Han population.

Keywords: GRM7, Noise-induced hearing loss, Polymorphism

\footnotetext{
* Correspondence: chinastress@sina.com

${ }^{2}$ Henan Provincial Institute for Occupational Health, No.3, Kangfu Mid. St,

Zhengzhou 450052, People's Republic of China

Full list of author information is available at the end of the article
}

(c) The Author(s). 2018 Open Access This article is distributed under the terms of the Creative Commons Attribution 4.0 International License (http://creativecommons.org/licenses/by/4.0/), which permits unrestricted use, distribution, and reproduction in any medium, provided you give appropriate credit to the original author(s) and the source, provide a link to the Creative Commons license, and indicate if changes were made. The Creative Commons Public Domain Dedication waiver (http://creativecommons.org/publicdomain/zero/1.0/) applies to the data made available in this article, unless otherwise stated. 


\section{Background}

With the widely spread of industrialization in the world, noise exposure is becoming more common in the industrial settings. This phenomenon is more noteworthy in developing countries. Nowadays, hearing loss due to occupational noise exposure is still an intractable problem for both developing and developed countries, and a lot of studies on noise are mainly focused on occupational NIHL [1]. World Health Organization studies show that occupational NIHL, as the second occupational health hazard except unintentional injuries, accounts for $16 \%$ of occupational chronic diseases and 19\% of the loss of health life induced by noise exposure in work place $[2,3]$. About 22 million U.S. workers are exposed to harmful noise level in the working environment every year and NIHL is one of the most common occupational diseases in the United States $[4,5]$. In China, occupational NIHL is the third most harmful occupational disease, accounting for one-sixth in all of the annual increased occupational diseases recently [6].

It has been well known that NIHL is a complicated disease caused by the interaction of genetic and environmental factors. The environmental factors, such as noise exposure, organic solvents, ototoxic drugs, heat, vibrations, smoking and health relative factors (hypertension, high cholesterol, pigmentation) and so on, all have essential effect on the progress of NIHL and a lot of work on preventing the harmful effect induced by these factors has been done. However, studies on human genetic factors which may be associated with the susceptibility to NIHL are relatively rare [7]. Researches on the knockout mice, for example $\mathrm{Pjvk}^{-/-}$[8], $P M C A 2^{+/-}$[9], $P 2 R X 2^{-/-}$ [10], $\mathrm{CDH} 23^{+/-}$[11], $\mathrm{SOD}^{-/-}$[12], GPX1 $1^{-/-}$[13], have indicated that the gene deficiency mice are more susceptible to NIHL. Current studies have shown that the polymorphisms of potassium ion channel genes (like KCNQ4 and $K C N E 1)$ [14, 15], catalase $(C A T)$, protocadherin 15 (PCDH15), myosin 14 (MYH14) [16] and heart shock protein (HSP70) [17] detected in different populations are significantly related to the development of NIHL. In addition, studies conducted by our research group has also found that heart shock protein (HSP70) [18], eye absent homolog 4 (EYA4) [19], suggestive POUdomain transcription POU4F3 and Grainyhead-like2 (GRHL2) [20] may be associated with the susceptibility to NIHL.

Up to now, when it comes to GRM7, previous studies have shown that GRM7 polymorphisms are associated with the susceptibility to hearing loss in the elderly [21-23], but the relationship between GRM7 polymorphisms and NIHL susceptibility remains to be further validated. At present, many researches have shown that glutamate is the main excitatory neurotransmitter in the transmission of inner hair cells and type I spiral ganglion neurons [24, 25]. High concentration of glutamate is neurotoxic, which has been known to be associated with NIHL [21, 26]. Metabotropic glutamate receptor 7 (mGluR7) encoded by GRM7 can reduce excessive glutamate release in the synaptic compartments to maintain their normal physiological concentration [21]. High-level noise exposure leads to the excessive release of glutamate from the hair cells to the synaptic cleft and the high concentration of glutamate overstimulates the postsynaptic cells or dendrites, causing them excitatory poisoning with the feature of swelling [27-29].

Hence, we hypothesize that GRM7 polymorphisms may have an effect on the development of NIHL. Then, we screen single nucleotide polymorphisms (SNPs) of GRM7 that may be related to the susceptibility of NIHL and carry out a nested case-control study in the occupational populations to analyze the relationship between GRM7 polymorphisms and NIHL.

\section{Methods \\ Subjects}

A dynamic cohort was established in a big steel factory among lasting noise exposure workers On January 1, 2006. Occupational health examinations, hearing tests and questionnaire surveys were carried out among the 6886 works selected into the cohort in the first year. And then noise, heat, toxic and hazardous substances in the work environment were monitored and measured every year. Health examination and hearing test were conducted every two years for the studying population. Up to December 31, 2015, there were 6297 subjects completed more than twice health examinations and hearing tests and 817 subjects finished only once. In the process of follow-up, 559 subjects joined in the research and 331 subjects were loss to follow-up because of resignation or being transferred to other positions.

In the cohort, there were 9 individuals with a history of being an airman, 76 with a history of being an artillerist, 53 with a history of head trauma, 3 with a history of blast exposure hearing damage, 10 with a history of eardrum perforation, 1 with a history of taking ototoxic drugs, 32 with a familial history of deafness, 15 with a history of rubella, 4 with a history of Meniere's syndrome, all of which were excluded in the case and control selecting.

This research based on the cohort study with 1 case to 2 controls matched. The case group (hearing loss group) and the control group were selected with the level of occupational noise exposure $\geq 80 \mathrm{~dB}(\mathrm{~A})$ and the time of accumulated occupational noise exposure $\geq 3$ years. The inclusion of cases was that binaural average hearing threshold levels (HTLs) in high frequencies $(3 \mathrm{kHz}, 4 \mathrm{kHz}, 6 \mathrm{kHz}) \geq$ $40 \mathrm{~dB}(\mathrm{~A})$. The control group matched with the same sex, the age difference $\leq 5$ years old and the same type of work, 
duration of occupational noise exposure $\leq 2$ years and was selected according to the HTL of any one ear in linguistic frequencies $(0.5 \mathrm{kHz}, 1 \mathrm{kHz}, 2 \mathrm{kHz})<25 \mathrm{~dB}(\mathrm{~A})$ and average binaural HTL in high frequencies $<35 \mathrm{~dB}(\mathrm{~A})$. Finally, there were 292 cases and 584 controls entering into this study.

The study was approved by the Ethics Committee of Henan Provincial Institute for Occupational Health (Ethical approval no.: 2,013,003) and informed consent was signed by all study participants or their agents.

\section{Epidemiological survey}

A combinative method of investigators interviewing and respondents actively reporting were used to collect information. Investigators had been professionally trained in advance. The questionnaire of this study mainly included the following aspects: (1) demographic characteristics: such as age, gender, date of birth, educational level, etc. (2) professional history: such as type of work, noise exposure duration in noise setting, environmental noise exposure level, etc. (3) living habits: such as, whether smoking and daily smoking levels, whether drinking and daily alcohol consumption, high-fat food intake, etc. (4) previous history of diseases affecting hearing: such as, ear trauma, tinnitus, sudden deafness, hypertension, etc. (5) history of ototoxic drug use, such as: aminoglycosides or vancomycin antibiotics, containing cisplatin and other anti-tumor drugs, containing arsenic and other heavy metal drug use history and so on. The detailed questionnaire was offered in the supplementary file [see Additional file 1].

Smokers were those smoking at least one cigarette every day and more than 6 months, otherwise, they were regared as non-smokers. The criterion for judging drinkers was that subjects drank at least once per week more than 1 year, if not, they were thought as nondrinkers.

\section{Hearing test and ear examination}

Before the examination, all the subjects were required to leave the occupational noise environment for at least 12 h. 216 audiometers (Interacoustics AS Company, Denmark) calibrated previously were used to test binaural air and bone conduction threshold audiometry at
$0.5,1,2,3,4,6 \mathrm{kHz}$. The surrounding should be quiet and the noise background value $<25 \mathrm{~dB}(\mathrm{~A})$. The results of the tests were collected by age and gender.

\section{Calculation of CNE}

The equivalent continuous sound level (A) $\left(\mathrm{L}_{\text {Aeq, }}\right.$ 8h $)$ was measured using Noisepro multi-functional individual noise dosimeters (NoisePro series, Quest Technologies, USA) which were adjuested by type of QC-10 Sound calibrators before measurement. The noise dosimeters were set as weight of A, S (slow), the value of $\mathrm{L}_{\text {Aeq, } 8 \mathrm{~h}}$ and then the CNE for every subjects was calculated based on the Fig. 1 (the Footnotes of Fig. 1 at the end of the article) [6].

\section{DNA extraction}

Peripheral blood ( $\geq 2 \mathrm{ml}$ ) was collected in the EDTA anticoagulant tube and stored at minus $80{ }^{\circ} \mathrm{C}$. The DNA of the peripheral blood was extracted using a $2 \mathrm{ml}$ blood genomic DNA extraction kit (Shanghai Laifeng Biotech, Shanghai, Chnia). The concentration and purity of DNA were measured using the NanoPhotometer P360 ultramicro spectrophotometer (Shanghai Boyibio Biotech, Shanghai, China). The prerequisites for subsequent DNA genotyping were that the A260/A280 value was between 1.8 and 2.0 and the concentration was $>50 \mathrm{ng} / \mu \mathrm{L}$.

\section{SNP selection and genotyping}

SNPs were selected according to the 1000 Genomes Project resources (http://www.internationalgenome.org/) and relative literatures and the inclusion criteria were as follows:

(1) sites of SNPs laid in the area of GRM7 with the minor allele frequency $(\mathrm{MAF})>0.10$ in the Chinese Han population;

(2)the linkage disequilibrium (LD) method of SNPs with the pairwise $r^{2}>0.80$.

Five SNPs in GRM7 were selected in this study.

In this study, the SNPs were genetyped using the SNPscan multiplex SNP genotyping kits (Genesky Biopharm Technology, Shanghai, China). AB13730XL DNA analyser was used to detect the sequence and

$$
\mathrm{CNE}=10 \log \left[\frac{1}{T_{\text {ref }}} \sum_{i=1}^{n}\left(T_{i} \times 10^{L_{A e q, 8 h / 10}}\right)\right]
$$

Fig. 1 The interpretation of CNE equation. Where Tref is equal to $1 ; n$ is the total number of different positions for the workers exposed to noise; $i$ is the number of different posts; $T$ is the time at different positions; $L_{\text {Aeq, }} 8 \mathrm{~h}$ is the equivalent continuous sound level of $8 \mathrm{~h}$ for different jobs 
GeneMapper 4.1 software (Applied Biosystems, USA) was utilized to analyze the genotype of SNP loci.

\section{Statistical analysis}

Data was analyzed using SPSS21.0 software. The continuous variables were implemented tests of normality and all of them were not in accordance with normal distribution, hence they were expressed by the median (range) and the differences between groups were analysed by Wilcoxon rank sum test. All of the classification variables were expressed by frequencies (percentile) and the comparisons between groups were analysed by pearson chi-square test.The control groups of SNPs were tested whether they were in line with Hardy-Weinberg equilibrium using Pearson's $x^{2}$ test. Four genetic models (additive model, dominant model, recessive, codominant model) were established and a conditional logistic regression was implemented to analyse the relationship between the polymorphisms of GRM7 and the susceptibility to NIHL. The interactions of genetic and environmental factors were also considered in logistic regression analysis by the option of multiplying interaction effect, and if the interactions were significant, then the stratification would be carried out to analyze the main effects. The generalised multiple dimensionality reduction software V.0.9 (GMDR V.0.9) was applied to find the interaction among SNPs. The possible confounders, such as CNE, smoking, drinking, hypertension, were adjusted during the statistical analysis. The test level was $\alpha=0.05$ therefore it was

Table 1 Basic Information Distribution in Case and Control Groups

\begin{tabular}{|c|c|c|c|c|}
\hline Variables & Case $(n=292)$ & Control $(n=584)$ & Statistics & $p$ \\
\hline \multicolumn{5}{|l|}{ Age, year } \\
\hline $20 \sim 30$ & $45(15.4 \%)$ & $104(17.8 \%)$ & & \\
\hline $30 \sim 40$ & 79 (27.1\%) & $153(26.2 \%)$ & & \\
\hline $40 \sim 50$ & $134(45.9 \%)$ & $270(46.2 \%)$ & & \\
\hline $50 \sim 60$ & $34(11.6 \%)$ & $57(9.8 \%)$ & $1.381^{\ddagger}$ & 0.710 \\
\hline Noise exposure duration, year & $18.860(8.500,27.750)$ & $18.509(8.167,26.917)$ & $-0.692^{\S}$ & 0.489 \\
\hline$C N E, d B(A)^{*}$ & $97.844(94.686,101.522)$ & $97.767(94.854,101.195)$ & $-0.153^{\S}$ & 0.878 \\
\hline$H T L, d B(A)^{+}$ & $50.980(44.042,55.833)$ & $18.293(12.500,24.000)$ & $-24.153^{\S}$ & $<0.001$ \\
\hline Height, cm & $170.366(167.000,174.750)$ & $169.993(166.000,174.000)$ & $-1.004^{\S}$ & 0.315 \\
\hline \multicolumn{5}{|l|}{ Gender } \\
\hline Male & $281(96.2 \%)$ & $560(95.9 \%)$ & & \\
\hline Female & $11(3.8 \%)$ & $24(4.1 \%)$ & $0.060^{\ddagger}$ & 0.807 \\
\hline \multicolumn{5}{|c|}{ level of environmental noise exposure, $\mathrm{dB}(\mathrm{A})$} \\
\hline$\leq 85$ & $121(41.4 \%)$ & 254 (43.5\%) & & \\
\hline$>85$ & $171(58.6 \%)$ & $330(56.5 \%)$ & $0.336^{\ddagger}$ & 0.562 \\
\hline \multicolumn{5}{|l|}{ Tinnitus } \\
\hline Yes & $196(67.4 \%)$ & $316(54.2 \%)$ & & \\
\hline No & $95(32.6 \%)$ & $267(45.8 \%)$ & $12.837^{\ddagger}$ & $<0.001$ \\
\hline \multicolumn{5}{|l|}{ Smoking } \\
\hline Yes & $181(62.0 \%)$ & 341 (58.4\%) & & \\
\hline No & 109 (38.0\%) & $243(41.6 \%)$ & $1.045^{\ddagger}$ & 0.307 \\
\hline \multicolumn{5}{|l|}{ Drinking } \\
\hline Yes & $203(69.5 \%)$ & 399 (68.3\%) & & \\
\hline No & 89 (30.5\%) & $185(31.7 \%)$ & $0.130^{\ddagger}$ & 0.718 \\
\hline \multicolumn{5}{|l|}{ Hypertension } \\
\hline Yes & $112(38.4 \%)$ & $242(41.4 \%)$ & & \\
\hline No & $180(61.6 \%)$ & $342(58.6 \%)$ & $0.768^{\ddagger}$ & 0.381 \\
\hline
\end{tabular}

Evaluation of the matching effects in the case and control groups by comparing the basic information distribution between them

"CNE: cumulative noise exposure

${ }^{\dagger} \mathrm{HTL}$ : the binaural average hearing threshold level in high frequencies

${ }^{\ddagger}$ Pearson chi-square test

${ }^{5}$ Wilcoxon rank sum test 


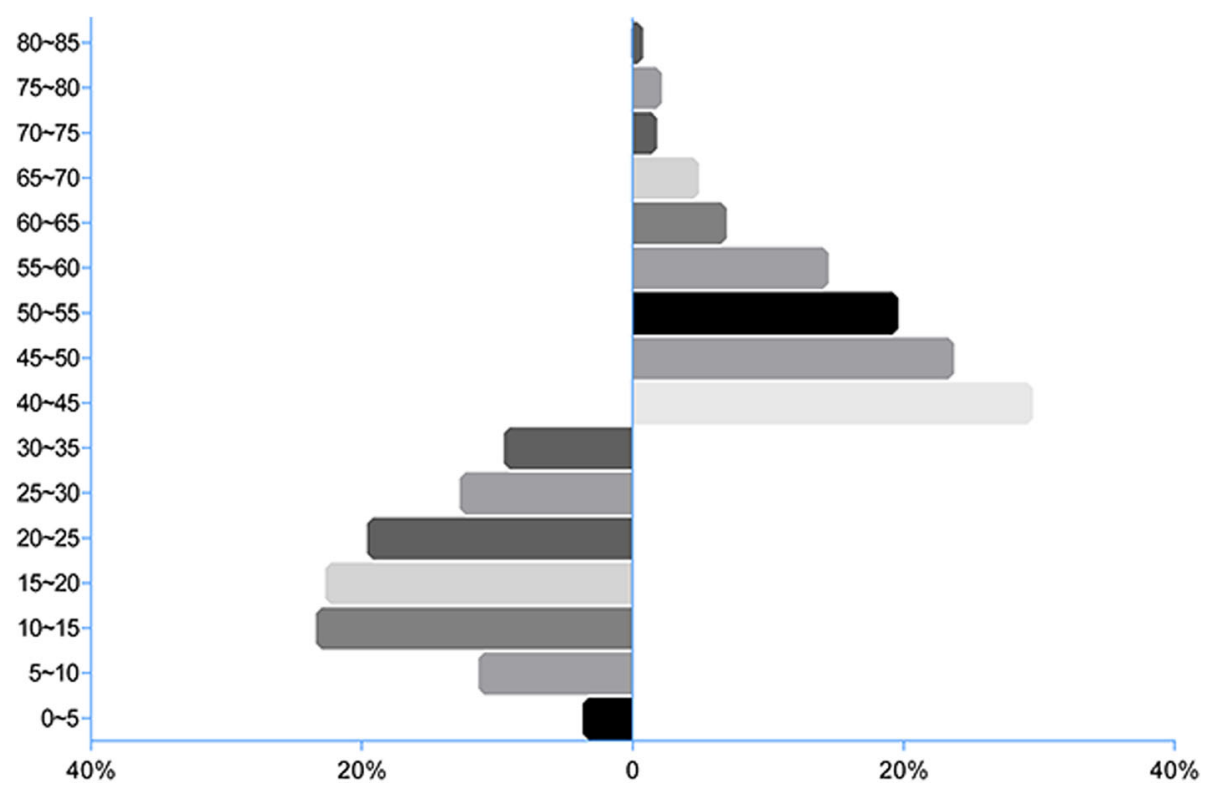

Fig. 2 The proportional distribution of the binaural average hearing threshold levels (HTLs) at $3 \mathrm{kHz}, 4 \mathrm{kHz}, 6 \mathrm{kHz}$ in case and control groups. HTL is grouped by $5 \mathrm{~dB}(\mathrm{~A})$ in both case and control groups. The control group ranges from 0 to $35 \mathrm{~dB}(\mathrm{~A})$ and the case group is in the range of 40 to $85 \mathrm{~dB}(\mathrm{~A})$

statistically significant if $p<0.05$. All the testing hypotheses were two-tailed. Bonferroni correction was used in the multiple comparing by pairs.

\section{Results}

Evaluation of matching effect in case and control groups In this study, a total of 876 people were involved, in which there were 292 cases and 584 controls, aging from 20.75 to 59.25 years old. As showed in Table 1 (after references), the matching effect was evaluated in the case and control groups through comparing the basic information distribution between them.

By test of normality, the whole continuous variables did not conform to the normal distribution, so nonparametric test was used. The classification variables were analysed by pearson $x^{2}$ test. The binaural average hearing threshold level (HTL) $(3 \mathrm{kHz}, 4 \mathrm{kHz}, 6 \mathrm{kHz})$ in the case group was higher than that of the control group, which conformed to the design needs of our research $(p$ $<0.001)$. What's more, the proportion of tinnitus in the case group was higher than that of the control group with $p<0.001$. Other comparisons in the case and control groups, including the general demographic characteristics (age, sex, height, noise exposure duration), individual factors (smoking, drinking), disease history (hypertension), and the observing indicators (CNE, level of environmental noise exposure) were of no significant difference $(p>0.05)$. The proportional distribution of HTL in case and control groups was showed in Fig. 2 (the Footnotes of Fig. 2 at the end of the article).

Table 2 Basic Information of the Selected SNPS

\begin{tabular}{|c|c|c|c|c|c|c|}
\hline \multirow[t]{2}{*}{$\overline{S N P}$} & \multirow[t]{2}{*}{ Chromosomal position } & \multirow[t]{2}{*}{$\mathrm{MAF}^{*}$} & \multicolumn{2}{|l|}{ Allele* } & \multirow[t]{2}{*}{$x^{2 b}$} & \multirow[t]{2}{*}{$p^{\dagger}$} \\
\hline & & & Ancestral allele & Mutant allele & & \\
\hline rs11920109 & Chr3:7,212,686 & 0.4016 & $T=0.4272$ & $C=0.5728$ & 2.4271 & 0.2178 \\
\hline rs1485175 & Chr3:7,620,789 & 0.4744 & $T=0.5437$ & $C=0.4563$ & 1.3677 & 0.2589 \\
\hline rs9819783 & Chr3:7,208,213 & 0.3848 & $\mathrm{~T}=0.4272$ & $C=0.5728$ & 1.5317 & 0.3961 \\
\hline rs9826579 & Chr3:7,782,371 & 0.3317 & $C=0.1408$ & $T=0.8592$ & 0.0185 & 0.9603 \\
\hline rs9877154 & Chr3:7,159,406 & 0.4187 & $T=0.3932$ & $C=0.6068$ & 0.1975 & 0.9045 \\
\hline
\end{tabular}

Hardy-Weinberg equilibrium test of all selected SNPs in the control group

${ }^{b}$ Pearson chi-square test is used to test whether the SNPs in the control group is in line with Hardy-Weinberg equilibrium

*The data comes from NCBI dbSNP and 1000 Genomes Browser (CHB)

${ }^{\dagger}$ Hardy-Weinberg Equilibrium Test of the control group by Pearson's $x^{2}$ 
Table 3 Correlation of Genetic Models with Risk of Developing NIHL

\begin{tabular}{|c|c|c|c|c|c|c|c|}
\hline \multirow[t]{2}{*}{ SNP } & \multirow[t]{2}{*}{ Genotype } & \multicolumn{2}{|c|}{ Case } & \multicolumn{2}{|c|}{ Control } & \multirow[t]{2}{*}{ OR $(95 \% \mathrm{Cl})^{*}$} & \multirow[t]{2}{*}{$p / p_{\text {bon }}{ }^{\dagger}$} \\
\hline & & $n$ & $\%$ & $n$ & $\%$ & & \\
\hline \multirow[t]{8}{*}{ rs11920109 } & $\Pi$ & 40 & 13.7 & 92 & 15.8 & 1 & $0.738 / 0.148$ \\
\hline & $\mathrm{TC}$ & 153 & 52.4 & 297 & 50.9 & $1.182(0.774,1.806)$ & $0.439 / 0.088$ \\
\hline & $\mathrm{CC}$ & 99 & 33.9 & 194 & 33.3 & $1.141(0.724,1.800)$ & $0.531 / 0.106$ \\
\hline & $\mathrm{CC}+\mathrm{TC}$ & 252 & 86.3 & 491 & 84.2 & $1.155(0.736,1.814)$ & $0.443 / 0.089$ \\
\hline & $\pi+\mathrm{TC}$ & 193 & 66.1 & 389 & 66.7 & 1 & \\
\hline & $\mathrm{CC}$ & 99 & 33.9 & 194 & 33.3 & $1.016(0.745,1.386)$ & $0.920 / 0.184$ \\
\hline & TT/TC/CC & & & & & $1.055(0.850,1.309)$ & $0.627 / 0.125$ \\
\hline & Allele $\mathrm{C} / \mathrm{T}$ & & & & & $1.039(0.866,1.246)$ & $0.682 / 0.136$ \\
\hline \multirow[t]{8}{*}{ rs1485175 } & $\Pi$ & 103 & 35.5 & 169 & 29.1 & 1 & $0.029 / 0.006$ \\
\hline & $\mathrm{TC}$ & 139 & 47.9 & 276 & 47.5 & $0.820(0.593,1.132)$ & $0.227 / 0.045$ \\
\hline & $\mathrm{CC}$ & 48 & 16.6 & 136 & 23.4 & $0.564(0.370,0.860)$ & $0.008 / 0.002$ \\
\hline & $\mathrm{CC}+\mathrm{TC}$ & 187 & 64.5 & 412 & 70.9 & $0.737(0.544,1.000)$ & $0.050 / 0.010$ \\
\hline & $\pi+T C$ & 242 & 83.4 & 445 & 76.6 & 1 & \\
\hline & $\mathrm{CC}$ & 48 & 16.6 & 136 & 23.4 & $0.636(0.437,0.925)$ & $0.018 / 0.004$ \\
\hline & TT/TC/CC & & & & & $0.761(0.620,0.934)$ & $0.009 / 0.002$ \\
\hline & Allele $\mathrm{C} / \mathrm{T}$ & & & & & $0.800(0.666,0.962)$ & $0.017 / 0.003$ \\
\hline \multirow[t]{8}{*}{ rs9819783 } & $\pi$ & 38 & 13.1 & 86 & 14.8 & 1 & $0.785 / 0.157$ \\
\hline & $\mathrm{TC}$ & 148 & 50.9 & 288 & 49.5 & $1.163(0.753,1.797)$ & 0.496/0.099 \\
\hline & $\mathrm{CC}$ & 105 & 36.1 & 208 & 35.7 & $1.150(0.728,1.816)$ & $0.550 / 0.110$ \\
\hline & $\mathrm{CC}+\mathrm{TC}$ & 253 & 86.9 & 496 & 85.2 & $1.158(0.765,1.752)$ & $0.489 / 0.098$ \\
\hline & $\pi+\mathrm{TC}$ & 186 & 63.9 & 374 & 64.3 & 1 & \\
\hline & $\mathrm{CC}$ & 105 & 36.1 & 208 & 35.7 & $1.024(0.751,1.396)$ & $0.881 / 0.176$ \\
\hline & TT/TC/CC & & & & & $1.054(0.848,1.309)$ & $0.637 / 0.127$ \\
\hline & Allele $\mathrm{C} / \mathrm{T}$ & & & & & $1.038(0.864,1.248)$ & $0.688 / 0.138$ \\
\hline \multirow[t]{8}{*}{ rs9826579 } & $\mathrm{CC}$ & 8 & 2.7 & 16 & 2.7 & 1 & $0.718 / 0.144$ \\
\hline & $\mathrm{CT}$ & 73 & 25.1 & 162 & 27.8 & $0.938(0.369,2.386)$ & $0.893 / 0.179$ \\
\hline & $\pi$ & 210 & 72.2 & 404 & 69.4 & $1.072(0.438,2.622)$ & $0.879 / 0.176$ \\
\hline & $\Pi+C T$ & 283 & 97.3 & 566 & 97.3 & $1.049(0430,2.559)$ & $0.917 / 0.183$ \\
\hline & $C C+C T$ & 81 & 27.8 & 178 & 30.6 & 1 & \\
\hline & $\pi$ & 210 & 72.2 & 404 & 69.4 & $1.136(0.833,1.549)$ & $0.422 / 0.084$ \\
\hline & $\mathrm{CC} / \mathrm{CT} / \mathrm{TT}$ & & & & & $1.106(0.844,1.451)$ & $0.465 / 0.093$ \\
\hline & Allele T/C & & & & & $1.086(0.849,1.390)$ & $0.510 / 0.102$ \\
\hline \multirow[t]{8}{*}{ rs9877154 } & $\pi$ & 41 & 14.0 & 86 & 14.7 & 1 & $0.712 / 0.142$ \\
\hline & $\mathrm{TC}$ & 147 & 50.3 & 278 & 47.6 & $1.125(0.737,1.719)$ & $0.585 / 0.117$ \\
\hline & CC & 104 & 35.6 & 220 & 37.7 & $0.995(0.636,1.556)$ & $0.983 / 0.197$ \\
\hline & $\mathrm{CC}+\mathrm{TC}$ & 251 & 86.0 & 498 & 85.3 & $1.071(0.715,1.604)$ & $0.740 / 0.148$ \\
\hline & $\pi+T C$ & 188 & 64.4 & 364 & 62.3 & 1 & \\
\hline & $\mathrm{CC}$ & 104 & 35.6 & 220 & 37.7 & $0.909(0.670,1.233)$ & $0.539 / 0.108$ \\
\hline & Tा/TC/CC & & & & & $0.973(0.787,1.202)$ & $0.799 / 0.160$ \\
\hline & Allele $\mathrm{C} / \mathrm{T}$ & & & & & $0.980(0.815,1.177)$ & $0.825 / 0.165$ \\
\hline
\end{tabular}

Effects of genetic models evaluated by conditional logistic regression

${ }^{*} \mathrm{CNE}$, height, smoking, drinking, and hypertension are adjusted; $\mathrm{Cl}$ : Confidence interval

${ }^{\dagger}$ Bonferroni correction is used to adjust $p$ values by means of $0.05 / 5$ ( 5 selected SNPs) to get $p_{\text {bon }}$ values of 0.01 , which means that it is significant in statistics

if $p_{\text {bon }}<0.01$ 
Table 4 Relationship between rs1485175 and NIHL layered by CNE

\begin{tabular}{|c|c|c|c|c|c|c|c|}
\hline \multirow[t]{2}{*}{ Environmental factor } & \multirow[t]{2}{*}{ Genotype } & \multicolumn{2}{|c|}{ Case } & \multicolumn{2}{|c|}{ Control } & \multirow[t]{2}{*}{ OR $(95 \% \mathrm{Cl})^{*}$} & \multirow[t]{2}{*}{$p / p_{\text {bon }}{ }^{\dagger}$} \\
\hline & & $\bar{n}$ & $\%$ & $\bar{n}$ & $\%$ & & \\
\hline \multicolumn{8}{|l|}{$\mathrm{CNE}, \mathrm{dB}(\mathrm{A})$} \\
\hline \multirow[t]{3}{*}{$<97$} & $\pi$ & 44 & 30.8 & 81 & 29.5 & 1 & $0.846 / 0.423$ \\
\hline & TC & 74 & 51.7 & 138 & 50.2 & $1.023(0.700,1.496)$ & $0.906 / 0.453$ \\
\hline & CC & 25 & 17.5 & 56 & 20.4 & $0.895(0.546,1.469)$ & $0.662 / 0.331$ \\
\hline \multirow[t]{3}{*}{$>97$} & $\pi$ & 61 & 40.9 & 91 & 29.4 & 1 & $0.047 / 0.024$ \\
\hline & $\mathrm{TC}$ & 65 & 43.6 & 138 & 44.7 & $0.784(0.550,1.118)$ & $0.179 / 0.090$ \\
\hline & CC & 23 & 15.4 & 80 & 25.9 & $0.550(0.340,0.891)$ & $0.014 / 0.007$ \\
\hline
\end{tabular}

The interaction between genes and the environment (CNE) analyzed by layering

*Height, smoking, drinking, and hypertension are adjusted

${ }^{\dagger}$ The statistically significant $p$ values are adjusted by Bonferroni correction through $0.05 / 2$ ( 2 groups layered by CNE) and it is statistically significant if $p_{\text {bon }}<0.025$

\section{Assessment of genotype effects on NIHL} Hardy-Weinberg equilibrium for control group

Table 2 (after references) showed that $p$ values in the control group of the selected SNPs were all above 0.05, which demonstrated that all SNPs in control group were in Hardy-Weinberg equilibrium (HWE) and the selected population of the control group was representative.

\section{Construction of genetic models and effect analysis}

Four genetic models were constructed for every SNP in this study: the additive model (wtwt, wtmt, mtmt), dominant model $[(\mathrm{mtmt}+\mathrm{wtmt})$ vs wtwt $]$, recessive model [mtmt vs (wtwt + wtmt)], codominant model (wtwt vs wtmt vs mtmt) (wt: wild type, mt: mutant type) and then conditional logistic regression analysis was conducted to evaluate the effect of the genetic models. Results in Table 3 (after references) indicated that in additive model CC genotype of rs1485175 had a protective effect to the risk of developing NIHL with an adjusted OR of $0.564\left(p / p_{\text {bon }}=0.008 / 0.002,95 \%\right.$ CI: $\left.0.370-0.860\right)$. But statistical association with NIHL was not found in TC genotype. In dominant model of rs1485175, statistical significant difference with a decreased risk was found $(p /$ $\left.p_{\text {bon }}=0.050 / 0.010, \mathrm{OR}=0.737,95 \% \mathrm{CI}: 0.554-1.000\right)$ and the associations in same direction were also detected in the recessive/codominant model and the allele $\mathrm{C} / \mathrm{T}$ with the $p / p_{\text {bon }}$ value of $0.018 / 0.004(\mathrm{OR}=0.636,95 \% \mathrm{CI}: 0.437-$ $0.925), 0.009 / 0.002(\mathrm{OR}=0.761,95 \% \mathrm{CI}: 0.620-0.934)$ and 0.017/0.003 (OR = 0.800, 95\%CI: 0.666-0.962), respectively. No significant associations were discovered in any other four SNPs between the case and control groups.

\section{Interaction Analysis between Genes and Environment}

The interaction between genes and the environment (CNE) was analyzed by the option of multiplying interaction effect in logistic regression analysis. The analysis found that rs1485175 and CNE had a significant interaction in statistics with $\mathrm{p}=0.007$ and OR $=0.997$ (95\% CI: 0.995-0.999). Then, the main genotype effect in each layer $(<97 \mathrm{~dB}(\mathrm{~A})$ and $>97 \mathrm{~dB}(\mathrm{~A}))$ was figured out. Significant differences were found in $\mathrm{TT}$ and $\mathrm{CC}$ with the $\mathrm{CNE}>97 \mathrm{~dB}(\mathrm{~A})$. The specific results of the analysis could be found in Table 4 .

\section{Analysis of interaction effects among SNPs}

The generalized multifactor dimensionality reduction (GMDR) v0.9 was applied in this research to detect the interaction of the 5 selected SNPs in GRM7. Covariates, CNE, height, smoking, drinking, hypertension, were adjusted in the analysis by loading phenotype data. Table 5 (after references) provided the best model, testing balanced accuracy, cross-validation (CV) consistency, and

Table 5 Results of the best model identified by GMDR

\begin{tabular}{|c|c|c|c|c|}
\hline Best model ${ }^{*}$ & Testing balanced accuracy (\%) & $\mathrm{CV}_{\text {consistency }}{ }^{+}$ & $p^{\ddagger}$ & $p^{\S}$ \\
\hline rs1485175 & 52.62 & $10 / 10$ & 0.6230 & 0.135 \\
\hline rs1485175, rs9877154 & 50.89 & $4 / 10$ & 0.3770 & 0.141 \\
\hline rs11920109, rs1485175, rs9826579 & 53.55 & $9 / 10$ & 0.0547 & 0.037 \\
\hline rs11920109, rs1485175, rs9819783, rs9826579 & 51.09 & $7 / 10$ & 0.6230 & 0.126 \\
\hline rs11920109, rs1485175, rs9819783, rs9826579, rs9877154 & 50.59 & $10 / 10$ & 0.6230 & 0.403 \\
\hline
\end{tabular}

The analysis of the interaction of the 5 selected SNPs in GRM7

${ }^{*} \mathrm{CNE}$, height, smoking, drinking, hypertension are adjusted

${ }^{\dagger} \mathrm{CV}$ consistency means cross-validation consistency

${ }^{\ddagger}$ Based on sign test

${ }^{\S}$ Based on permutation test 
$p$ values by sign test. In all of the models the combination of rs1920109, rs1485175, rs9826579 formed the best model with a statistically significant $p$ value of 0.0547 , the maximum testing balanced accuracy of $53.55 \%$ and the biggest CV consistency (9/10). Permutation test appeared that the best model made of rs1920109, rs1485175, rs9826579 statistically significant $(p=0.037)$. Figure 3 (the Footnotes of Fig. 3 at the end of the article) showed the best model constituted by rs11920109, rs1485175, rs9826579.

\section{Discussion}

The whole genome association study has found that the T-allele of rs11928865 in GRM7 is associated with agerelated hearing loss (ARHI) in European group, which is also confirmed in an elderly male Han Chinese population and rs779706 and rs779701, the SNPs within GRM7, are significant in the Finnish group [21, 30]. Although the polymorphisms of GRM7 are an important factor affecting ARHI, genetic polymorphisms are also common in general population and they should also been involved in the study of NIHL.

Our results discovered for the first time that the mutant allele $\mathrm{C}$ in rs 1485175 of the GMR7 had significant associations with NIHL among the additive, dominant, recessive, codominant models and the allele $\mathrm{C} / \mathrm{T}$. The result suggests that $\mathrm{CC}$ genotype might act as a protective factor for the glutamate toxicity caused by high intensity noise exposure. That's to say in the same harmful noisy environment, individuals with non-CC genotype in rs1485175 of GRM7 are more susceptible than those who have CC genotype. But in our study we have not found the statistical correlation between the rs11928865 of GRM7 and the susceptibility to NIHL.

Many researches have demonstrated that NIHL is a disease resulted from the interaction of gene and environment. Therefore the interaction between rs1485175 and environmental factors and the interaction of rs1485175 with the other selected SNPs of GRM7 were analyzed. The results of the gene-by-environment interaction analysis suggest that $\mathrm{CNE}$ at higher level $(>97 \mathrm{~dB}(\mathrm{~A}))$ might interact with rs 1485175 with the $p$ value of 0.014 and OR of 0.550 (95\% CI: $0.340-0.891)$. The risk of developing NIHL reduces by 0.447 after stratification according to CNE, which suggests that CNE may be a risk factor for NIHL and workers are more susceptible to noise at the higher level of CNE [6]. The gene-by-gene interaction data obtained through the software of GMDR showed that the best model made up of rs11920109, rs1485175, rs9826579, suggesting that the main effect of the GRM7 gene on susceptibility to NIHL we have found is the combination of these three genes; that is, the influence of rs1485175 on NIHL is dependent on the genotypes of the other two SNPs in GRM7.

High glutamate concentration can lead to programmed death of the spiral ganglion neurites and cells, which is also verified by incubating spiral ganglion explants with a caspase-3 inhibitor (an inhibitor of apoptosis) [27]. Therefore, the negative feedback regulation of glutamate is important in maintaining the normal transmission of the sound signal in the ear. The mGluR7, Group III mGlu receptors, is principally situated in the presynaptic membrane and negatively

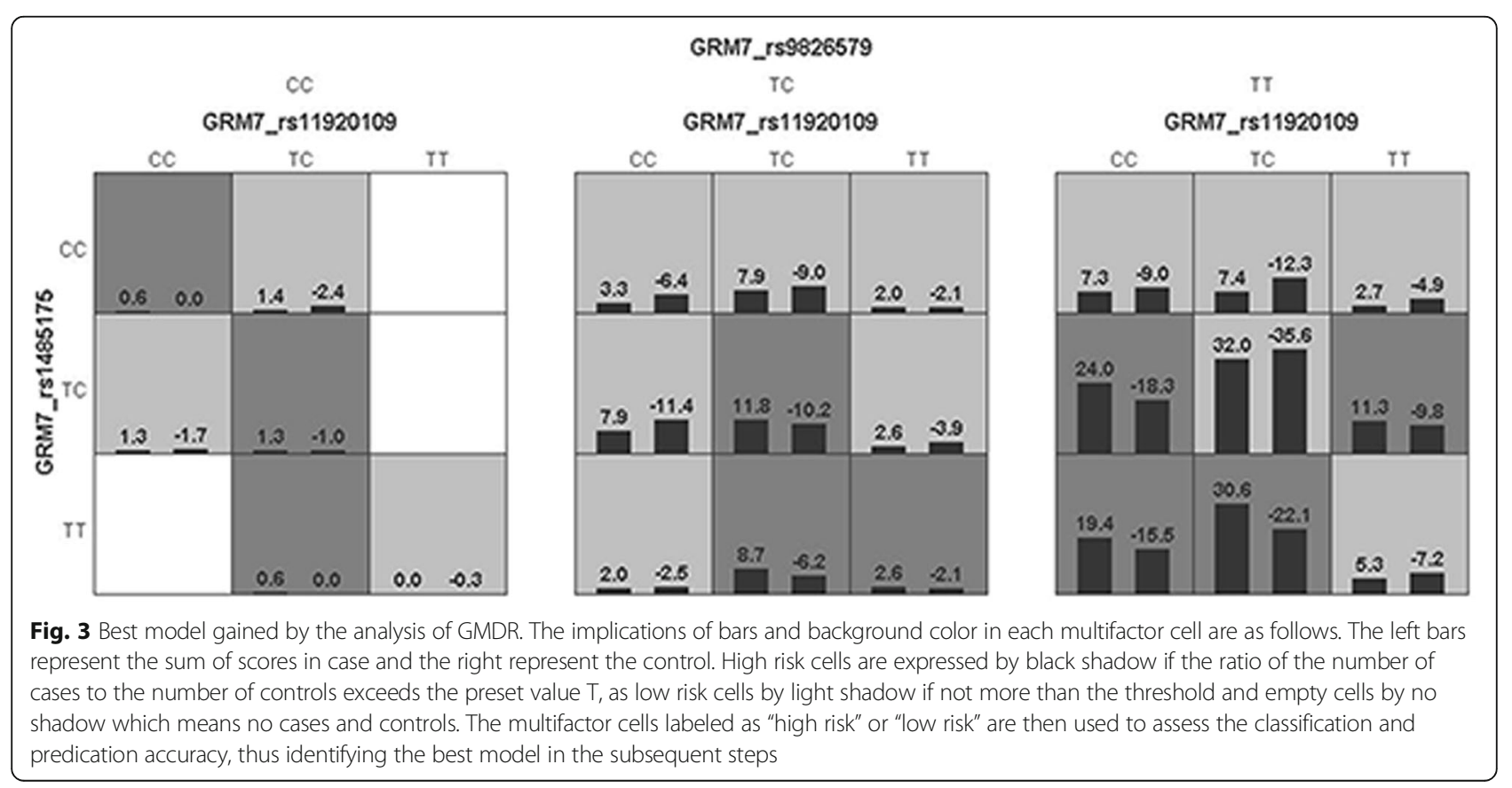


regulates the level of glutamate. The activation of mGluR7 can hinder glutamate releasing when exposed in high intensity noise level, which lowers the excitability of target cells and neurons, thus playing a protective role in glutamate excitotoxicity [31].

It is possible that the T-allele mutation to $\mathrm{C}$-allele in rs1485175 may take part in this process. In the normal inner hair cells and neurons, the mutant allele $\mathrm{C}$ in rs1485175 may increase the number of mGluR7 or enhance its sensitivity to glutamate in the presynaptic membrane, and then to accelerate the glutamate uptake or reduce the release of glutamate when exposed to high intense noise, thus avoiding the glutamate excitotoxicity. That may be the reason why individuals with CC genotype of rs1485175 in GRM7 are less susceptible to noise than non-CC genotype. CNE [6], height [32], smoking [33], drinking [34, 35], and hypertension [35], which are all hazardous factors for NIHL, were adjusted in the process of analyzing.

Advantages for this study are as follows. Firstly, a nested case-control study used in our study can better overcome the selection bias and recall bias, as well as reducing costs. Secondly, more accurate measurements than previous studies are used, including the intensity of noise exposure, the diagnosis of NIHL and the principle of double blind and so on. Some limitations of this study should also be known. It has been known that exposing to noise coming from living environment and individual activities for a long time can also cause hearing impairment [36], but the effect is smaller and less hazardous compared with NIHL due to noise exposure in the working place [37]. Namely, the results of our study are authentic.

\section{Conclusions}

In summary, we find for the first time that the mutant allele C of rs1485175 in GRM7 may reduce the susceptibility of individuals to NIHL in Chinese Han population. At the same time, we also note that the gene-by-environmental and gene-by-gene interactions may affect the protective effect of mutant allele $C$ in rs1485175 of GRM7. This finding, once verified by large studies, will have important implications in the prevention of NIHL in susceptible occupational population.

\section{Additional file}

Additional file 1: The supplementary material was designed for this study. The data in the questionnaire titled "the Questionnaire of Occupational Health" and they contained the basic demographic information of the workers, the information of smoking and drinking, occupational history, the history of past disease and drug use, family history of deafness, work-related injuries and other information related to the occupational health. (DOCX $45 \mathrm{~kb}$ )

\section{Abbreviations}

ARHI: Age-related hearing loss; CNE: Cumulative noise exposure; GMDR: Generalized multiple dimensionality reduction; GRM7: Metabolic glutamate receptor7 gene; HTLs: Hearing threshold levels; HWE: Hardy-
Weinberg equilibrium; LD: Linkage disequilibrium; MAF: Minor allele frequency; mGluR7: Metabotropic glutamate receptor 7; mt: Mutant type; NIHL: Noise-induced hearing loss; SNPs: Single nucleotide polymorphisms; wt: Wild type

\section{Acknowledgements}

Not applicable

\section{Funding}

This research was funded by the National Natural Science Foundation of China and National Science and Technology Support Program (81,372,940 and 2014BAI12B03).

\section{Availability of data and materials}

The data that support the findings of this study are not publicly available due to the issue of intellectual property but are available from the corresponding author on reasonable request.

\section{Authors' contributions}

SY made substantial contributions to the design of the study, the process of implementation and the revision of the final manuscript. YZ had offered many intellectual conceptions in the beginning of the subject and revised the final manuscript. GC, HZ and GG provided human and material support in the data collection and revised the final manuscript. JJ, WZ, HW and YL participated in the collection of data both in the epidemiological survey and the laboratory testing and revised the final manuscript. YY contributed to the interpretation of important information and the modification of this paper. PY has analyzed the data and written this paper. All authors have read and approved the final manuscript.

\section{Ethic approval and consent to participate}

The study was approved by the Ethics Committee of Henan Provincial Institute for Occupational Health (Ethical approval no.: 2,013,003) and informed consent was signed by all participants or their agents.

\section{Consent for publication}

Not applicable

Competing interests

The authors declare that they have no competing interests.

\section{Publisher's Note}

Springer Nature remains neutral with regard to jurisdictional claims in published maps and institutional affiliations.

\section{Author details}

${ }^{1}$ Department of Occupational and Environmental Health Hygiene, College of Public Health, Zhengzhou University, Zhengzhou, Henan, People's Republic of China. ${ }^{2}$ Henan Provincial Institute for Occupational Health, No.3, Kangfu Mid. St, Zhengzhou 450052, People's Republic of China. ${ }^{3}$ Wugang Institute for Occupational Health, Wugang, Henan, People's Republic of China. ${ }^{4}$ College of Public Health, Qingdao University, Qingdao, Shandong, People's Republic of China. ${ }^{5}$ National Institute of Occupational Health and Poison Control, Chinese Center for Disease Control and Prevention, Beijing, People's Republic of China.

Received: 6 September 2017 Accepted: 19 December 2017

Published online: 05 January 2018

\section{References}

1. Basner M, Babisch W, Davis A, Brink M, Clark C, Janssen S, Stansfeld S. Auditory and non-auditory effects of noise on health. Lancet. 2014; 383(9925):1325-32.

2. Corvalan. aPUJLSTC: Chapter 21 Selected occupational risk factors. comparative quantification of Health risks. global and regional Burden of disease attributable to selected major risk factors. 2004, Vol 2(1651-1802.

3. WHO: Protecting workers' health. 2014. [http://www.who.int/mediacentre/ factsheets/fs389/en/]. Accessed 25 June 2017.

4. Leigh JP. Hearing impairment among noise-exposed workers - United States, 2003-2012. Milbank Q. 2011;89(4):728-72. 
5. NIOSH: NIOSE AND HEARING LOSS PREVENTION. [https://www.cdc.gov/ niosh/topics/noise/prevention.html]. 2016. Assessed 26/06/2017.

6. SF Y, Chen G, Jiao J, GZ G, Zhang HL, Wang XM, Zhou WH, Wu H, Li YH, Zheng YX. A cohort study on occupational noise induced hearing loss in workers at an iron and steel plant. Chinese Journal of Preventive Medicine. 2017:51(1):13-9.

7. Konings A, Van Laer L, Van Camp G. Genetic studies on noise-induced hearing loss: a review. Ear Hear. 2009;30(2):151-9.

8. Delmaghani S, Defourny J, Aghaie A, Beurg M, Dulon D, Thelen N, Perfettini I, Zelles T, Aller M, Meyer A, et al. Hypervulnerability to sound exposure through impaired adaptive proliferation of peroxisomes. Cell. 2015;163(4): 894-906.

9. Kozel PJ, Davis RR, Krieg EF, Shull GE, Erway LC. Deficiency in plasma membrane calcium ATPase isoform 2 increases susceptibility to noiseinduced hearing loss in mice. Hear Res. 2002;164(1-2):231-9.

10. Housley GD, Morton-Jones R, Vlajkovic SM, Telang RS, Paramananthasivam V, Tadros SF, Wong AC, Froud KE, Cederholm JM, Sivakumaran Y, et al. ATPgated ion channels mediate adaptation to elevated sound levels. Proc Natl Acad Sci U S A. 2013;110(18):7494-9.

11. Holme RH, Steel KP. Progressive hearing loss and increased susceptibility to noise-induced hearing loss in mice carrying a Cdh23 but not a Myo7a mutation. J Assoc Res Otolaryngol. 2004;5(1):66-79.

12. Ohlemiller KK, McFadden SL, Ding DL, Flood DG, Reaume AG, Hoffman EK, Scott RW, Wright JS, Putcha GV, Salvi RJ. Targeted deletion of the cytosolic cu/Zn-superoxide dismutase gene (Sod1) increases susceptibility to noiseinduced hearing loss. Audiol Neurootol. 1999;4(5):237-46.

13. Ohlemiller KK, McFadden SL, Ding D-L, Lear PM, Ho Y-S. Targeted mutation of the gene for cellular glutathione peroxidase (Gpx1) increases noiseinduced hearing loss in mice. J Assoc Res Otolaryngol. 2000;1 (3):243-54.

14. Van Laer L, Carlsson Pl, Ottschytsch N, Bondeson ML, Konings A, Vandevelde A, Dieltjens N, Fransen E, Snyders D, Borg E, et al. The contribution of genes involved in potassium-recycling in the inner ear to noise-induced hearing loss. Hum Mutat. 2006;27(8):786-95.

15. Pawelczyk M, Van Laer L, Fransen E, Rajkowska E, Konings A, Carlsson PI, Borg E, Van Camp G, Sliwinska-Kowalska M. Analysis of gene polymorphisms associated with $\mathrm{K}$ ion circulation in the inner ear of patients susceptible and resistant to noise-induced hearing loss. Ann Hum Genet. 2009;73(Pt 4):411-21.

16. Konings A, Van Laer L, Wiktorek-Smagur A, Rajkowska E, Pawelczyk M, Carlsson PI, Bondeson ML, Dudarewicz A, Vandevelde A, Fransen E, et al. Candidate gene association study for noise-induced hearing loss in two independent noise-exposed populations. Ann Hum Genet. 2009;73(2):215-24.

17. Yang $\mathrm{M}$, Tan $\mathrm{H}$, Yang $\mathrm{Q}$, Wang $\mathrm{F}$, Yao $\mathrm{H}$, Wei Q, Tanguay RM, Wu T. Association of hsp70 polymorphisms with risk of noise-induced hearing loss in Chinese automobile workers. Cell Stress Chaperones. 2006;11(3):233-9.

18. Li YH, Yu SF, Gu GZ, Chen GS, Zheng YX, Jiao J, Zhou WH, Wu H, Zhang ZR, Zhang $\mathrm{HL}$, et al. Polymorphisms of heat shock protein 70 genes (HSPA1A, HSPA1B and HSPA1L) and susceptibility of noise-induced hearing loss in a Chinese population: a case-control study. PLoS One. 2017;12(2):e0171722.

19. Yang QY, XR X, Jiao J, Zheng YX, He LH, SF Y, GZ G, Chen GS, Zhou WH, Wu $\mathrm{H}$, et al. Genetic variation in EYA4 on the risk of noise-induced hearing loss in Chinese steelworks firm sample. Occup Environ Med. 2016;73(12):823-8.

20. XR X, Yang QY, Jiao J, He LH, SF Y, JingWang J, GZ G, Chen GS, Zhou WH, Wu H, et al. Genetic variation in POU4F3 and GRHL2 associated with noiseinduced hearing loss in Chinese population: a case-control study. Int J Environ Res Public Health. 2016;13(561):14.

21. Friedman RA, Laer LV, Huentelman MJ, Sheth SS, Eyken EV, Corneveaux JJ, Tembe WD, Halperin RF, Thorburn AQ, Thys S, et al. GRM7 variants confer susceptibility to age-related hearing impairment. Hum Mol Genet. 2009; 18(4):785-96.

22. Newman DL, Fisher LM, Ohmen J, Parody R, Fong CT, Frisina ST, Mapes F, Eddins DA, Robert Frisina D, Frisina RD, Friedman RA. GRM7 variants associated with age-related hearing loss based on auditory perception. Hear Res. 2012;294(1-2):125-32.

23. Van Laer L, Huyghe JR, Hannula S, Van Eyken E, Stephan DA, Maki-Torkko E, Aikio P, Fransen E, Lysholm-Bernacchi A, Sorri M, et al. A genome-wide association study for age-related hearing impairment in the Saami. Eur J Hum Genet. 2010;18(6):685-93.

24. Puel JL. Chemical synaptic transmission in the cochlea. Prog Neurobiol. 1995;47(6):449-76.
25. Hakuba N, Koga K, Gyo K, Usami SI, Tanaka K. Exacerbation of noise-induced hearing loss in mice lacking the glutamate transporter GLAST. J Neurosci. 2000;20(23):8750-3.

26. Pujol R, J-L Puel, D'aldin CG, Eyblin M. Pathophysiology of the glutamatergic synapses in the cochlea. Acta Otolaryngol. 2009;113(3):330-4.

27. Steinbach S, Lutz J. Glutamate induces apoptosis in cultured spiral ganglion explants. Biochem Biophys Res Commun. 2007;357(1):14-9.

28. Eybalin M, Norenberg MD, Renard N. Glutamine synthetase and glutamate metabolism in the guinea pig cochlea. Hear Res. 1996;101(1-2):93-101.

29. Henderson $\mathrm{D}$, Bielefeld $\mathrm{EC}$, Harris $\mathrm{KC}, \mathrm{BH}$ H. The role of oxidative stress in noise-induced hearing loss. Ear Hear. 2006;27(1):1-19.

30. Luo HJ, Yang T, Jin XJ, Pang XH, Li JP, Chai YC, Li L, Zhang Y, Zhang LP, Zhang $Z \mathrm{H}$, et al. Association of GRM7 variants with different phenotype patterns of age-related hearing impairment in an elderly male Han Chinese population. PLoS One. 2013:8(10):e77153.

31. Williams CJ, Dexter DT. Neuroprotective and symptomatic effects of targeting group III mGlu receptors in neurodegenerative disease. J Neurochem. 2014; 129(1):4-20.

32. Burr H, Lund SP, Bügel Sperling B, Kristensen TS, Poulsen OM. Smoking and height as risk factors for prevalence and 5-year incidence of hearing loss. A questionnaire-based follow-up study of employees in Denmark aged 18-59 years exposed and unexposed to noise. Int J Audiol. 2009;44(9):531-9.

33. Tao L, Davis R, Heyer N, Yang Q, Qiu W, Zhu L, Li N, Zhang H, Zeng L, Zhao $Y$. Effect of cigarette smoking on noise-induced hearing loss in workers exposed to occupational noise in China. Noise Health. 2013;15(62):67-72.

34. Upile T, Sipaul F, Jerjes W, Singh S, Nouraei SA, El Maaytah M, Andrews P, Graham J, Hopper C, Wright A: The acute effects of alcohol on auditory thresholds. BMC Ear Nose Throat Disord 2007, 7(4.

35. Przewozny T, Gojska-Grymajlo A, Kwarciany M, Gasecki D, Narkiewicz K. Hypertension and cochlear hearing loss. Blood Press. 2015;24(4):199-205.

36. Hammer MS, Swinburn TK, Neitzel RL. Environmental noise pollution in the United States: developing an effective public health response. Environ Health Perspect. 2014;122(2):115-9.

37. Lie A, Skogstad M, AH, Johannessen, Tynes T, Mehlum IS, Nordby K-C, Engdahl B, Tambs K: Occupational noise exposure and hearing: a systematic review. Int Arch Occup Environ Health 201689):351-372.

\section{Submit your next manuscript to BioMed Central and we will help you at every step:}

- We accept pre-submission inquiries

- Our selector tool helps you to find the most relevant journal

- We provide round the clock customer support

- Convenient online submission

- Thorough peer review

- Inclusion in PubMed and all major indexing services

- Maximum visibility for your research

Submit your manuscript at www.biomedcentral.com/submit
) Biomed Central 